\title{
Öğretmen Adaylarının Epistemolojik İnançları İle Ders Çalışma Yaklaşımlarının Çeşitli Değişkenler Açısından İncelenmesi
}

\author{
DOI: $10.26466 /$ opus. 887464
}

*

\author{
İlhami Arseven* - Mustafa Ersoy ** - Aylin Taşdemircanan ${ }^{* * *}$ \\ * Dr. Öğr. Üyesi, Sivas Cumhuriyet Üniversitesi, Eğitim Fakültesi, Sivas/Türkiye \\ E-Posta: iarseven@cumhuriyet.edu.tr \\ ORCID: 0000-0001-9750-5862 \\ ** Dr. Öğr.Üyesi, Sivas Cumhuriyet Üniversitesi, Eğitim Fakültesi, Sivas/Türkiye \\ E-Posta: mstfrsy@gmail.com \\ ORCID: 0000-0002-7320-8844 \\ *** Öğretmen, Milli Eğitim Bakanlığı, Sivas/Türkiye \\ E-Posta: aylintasdemircanan@gmail.com \\ ORCID: $\underline{0000-0002-1651-8942}$
}

Öz

Bu araştırmada, öğretmen adaylarmın epistemolojik inançları ve ders çalışma yaklaşımları çeşitli değişkenlere göre incelenmiştir. Araştırma modeli olarak tarama (survey) modeli kullanılmıştır. Araştırmanın evrenini Sivas Cumhuriyet Üniversitesi Eğitim Fakültesinde öğrenim gören öğretmen adayları oluştururken, araştırmanm çalışma grubunu PDR(39), Fen Bilgisi Öğretmenliği (27), Stmı Öğretmenliği (22), Okul Öncesi Öğretmenliği (51), Türkçe Öğretmenliği (39) bölümlerinde son smifta öğrenim gören toplam 178 öğretmen adayı oluşturmaktadır. Veriler, Conley ve arkadaşları (2004) tarafindan geliştirilen; çeviri, uyarlama (üniversite öğrencileri için), geçerlik ve güvenirlik çalışması Akçay, Gezer ve Akçay (2016) tarafindan yapılmış olan "Epistemolojik İnanç Ölçeği (EIÖ)" ve Biggs, Kember ve Leung (2001) tarafindan geliştirilen, çeviri, uyarlama, geçerlik ve güvenirlik çalışması Yılmaz ve Orhan (2011) tarafindan yapılan "Ders Çalışma Yaklaşımı Ölçeği (DÇYÖ)" kullanılmıştır. Ayrıca çalışma grubunda yer alan öğretmen adaylarının kişisel niteliklerini ortaya koymak amactyla araştırmacılar tarafindan geliştirilen "Kişisel Bilgi Formu" kullanılmıştır. Araştırmanın sonunda; öğretmen adaylarımı Epistemolojik İnanç Ölçeğinin tamammdan ve alt boyutlarından aldıkları puanlar arasında cinsiyete göre anlamlı bir fark olmadığı, Ders Çalışma Yaklaşımı Ölçeğinin "yüzeysel yaklaşım" alt boyutunda ise erkek öğretmen adaylarını aldıkları puanları, kadın öğretmen adaylarının puanlarma göre anlaml derecede yüksek olduğu, PDR bölümünde öğrenim gören öğretmen adaylarmın Eİ̈ "bilginin gelişimi" alt boyutundaki puanlarının Stmı ve Fen Bilgisi Öğretmenliği bölümünde öğrenim gören öğretmen adaylarının puanlarına göre anlamlı derecede yüksek olduğu belirlenmiştir. Yine öğretmen adaylarmm Epistemolojik İnanç Ölçeğinin tamamından ve alt boyutlarından aldıkları puanlar arasında kitap okuma sıklı̆ına göre anlamlı bir fark olmadığı, Ayda birden fazla kitap okuyan öğretmen adaylarını DÇYÖ “derin yaklaşım” alt boyutundaki puanlarını üç ayda bir kitap okuyan öğretmen adaylarma göre anlaml derecede yüksekolduğu tespit edilmiştir. Ayrıca öğretmen adaylarını EİÖ "bilginin gerekçelendirilmesi" alt boyutundan aldiklar puanlar ile DÇYÖ "derin yaklaşım" alt boyutundan aldıkları puanlar arasında düşük düzeyde pozitif bir ilişki olduğu belirlenmiştir. Elde edilen bulgular literatüre dayalı olarak yorumlanmıs ve tartışlmıştır. Bütün bu sonuçlar çerçevesinde öğretmen adaylarını epistemolojik inançları ve ders çalışma yaklaşımlarım geliştirme konusunda eğitsel rehberlik faaliyetlerinin yürütülmesi, epistemolojik inanç ve ders çalışma yaklaşımlarmı etkileyecek olumsuzlukları giderilmesi için akademik çalışmaların yapılması önerilmektedir.

Anahtar Kelimeler: Epistemolojik inanç, ders çalışma yaklaşımı, öğretmen adayları. 


\title{
Examination of Epistemological Beliefs and Study Approaches of Teacher Candidates in Terms of Various Variables
}

\begin{abstract}
This study examined teacher candidates' epistemological beliefs and study approaches according to various variables. The study used survey model as the research model. The participants were 178 teacher candidates, who were senior students, studying at Sivas Cumhuriyet University Faculty of Education. In the analysis of the data, the researchers used "Epistemological Belief Scale (EBS)", which was developed by Conley et al. (2004) and was translated into Turkish, was adapted for university students and underwent validity and reliability studies by Akçay, Gezer and Akçay (2016), and "Study Process Questionnaire (SPQ)", which was developed by Biggs, Kember and Leung (2001) and was adapted to Turkish and underwent validity and reliability studies by Yilmaz and Orhan (2011). In addition, the "Personal Information Form", which was developed by the researchers, was used to reveal the personal qualities of the teacher candidates in the study group. The results of the study revealed no significant different in terms of gender variable between the scores of the teacher candidates from the whole Epistemological Belief Scale and its sub-dimensions. However, the results indicated a significant difference between the scores of the male teacher candidates and the scores of the female teacher candidates in the "surface approach" sub-dimension of the Study Process Questionnaire. Furthermore, the results indicated a significant difference between the scores of the teacher candidates studying in the Psychological Counseling and Guidance department and the scores of those studying in the Primary Education and Science Education departments in the "development of knowledge" subdimension of the EBS The results indicated no significant difference in terms the frequency of reading books variable between the teacher candidates' scores from the whole and sub-dimensions of the Epistemological Belief Scale, and the results indicated a significant difference in the "deep approach" sub-dimension of the SPQ between the teacher candidates who read more than one book per month and those who read a book every three months. In addition, the study determined that there was a low level positive relationship between the scores of the teacher candidates in the "justification of knowledge" sub-dimension of the EBS and the scores they got from the "deep approach" subdimension of the SPQ. The findings were interpreted and discussed based on the relevant literature. In the light of the results obtained in the study, the researchers suggested carrying out educational guidance activities for developing the epistemological beliefs and study processes of teacher candidates, and carrying out academic studies to eliminate the negativities that would affect the epistemological beliefs and study processes.
\end{abstract}

Keywords: Epistemological belief, study approach, teacher' candidates. 


\section{Giriş}

Bilginin üretilmesi, geliştirilmesi ve aktarılması eğitimin en temel görevlerinden biridir. Bununla birlikte bilginin ne olduğu, kaynağının neresi olduğu, kesin bilginin olup olamayacağı, bilginin yapısının kökeninin, sınırının ne olduğu gibi konular ise felsefenin bir alt kolu olan Epistemolojinin" çalışma alanına girmektedir (Büyükdüvenci, 1985). Epistemoloji, bilgi felsefesidir ve bilginin kaynağını, ölçütlerini, evrenselliğini ve kesinliğini ele alır (Turan, 2016). Bireyin nasıl öğrendiği konusu, bir anlamda farklı felsefelerin bilgiye bakış açılarıyla yakından ilgilidir. Zira öğrenmenin nasıl meydana geldiğine ilişkin ortaya atılan öğrenme kuramları, temellerini Epistemolojiden almışlardır. Yani deney ve gözlemlere dayalı olarak bilimsel yöntemlerle izah edilen öğrenmenin nasıl meydana geldiği hususunun düşünsel bir temeli vardır ki bu da bilgi felsefesi yani Epistemolojidir. Dolayısıyla öğrenme kuramlarının felsefi bir altyapısı mevcuttur.

Öğrenme ve bilgi birbirini etkileyen ve çok yakın ilişkili olan iki kavramdır. Öğrenme, duyu organlarıyla elde edilen verilerin anlamlandırılması ve bilgiye dönüştürülmesidir. Öğrenme bir bakıma "anlam çkarmadır". Bilgiye ve bilgilendirmeye yol açan bir süreçtir. Epistemolojinin bilgiye ilişkin olarak ortaya koyduğu bilgiler, aslında öğrenmenin tanımını da ortaya çıkarmaktadır. Bununla birlikte bilginin kaynağına, sınırlarına, evrenselliğine ya da kesinliğine ilişkin felsefenin tek bir cevabı bulunmamaktadır. Zira farklı felsefi yaklaşımlar bilginin doğasına ilişkin farklı düşüncelere sahiptirler. Bu düşünceler de farklı öğrenme tanımlarına neden olmaktadır. Bilginin doğasına ilişkin olarak üç temel felsefi akım karşımıza çıkmaktadır. Bunlar İdealizm, Realizm ve Pragmatizmdir.

Platon gibi ilkçağ düşünürlerinden beri süregelmiş İdealizm, dış dünyadaki varlıkların gerçek olmadığını, aklın ve düşüncenin bir ürünü olduğunu ileri sürmektedir. Akıl ve düşüncelerimizin varlığ rakimiz aslında dış dünyayı var eder. Düşünmeseydik, idrak etmeseydik, dış dünya diye bir şey olmayacaktı. Dış dünya dediğimiz şey, yalnızca duyumlarımızdır. Algılarımız ve düşüncelerimiz olmazsa dış dünya da, bir anlamda yoktur. Varlıklar ve nesneler bizim düşüncelerimizde vardır (Ergün, 2015). Dolayısıyla bilginin kaynağı akıldır. Platon'a göre bilgi, mutlak ve kesindir. İnsanlar doğuştan, kendilerinde var olan akıl sayesinde bilgiye de sahiptirler. Platonun bu anlayışı, onun metafizik olarak iki dünyanın 
ayrımına dayanır. Ona göre duyularla algılanan nesneler "idealar dünyasının" birer yansımasıdır ve gerçek değildir. Gerçek olan ise bu nesnelerin düşünsel formları olan idelerdir. İdeler ise duyularla değil, akıl ve düşünme ile kavranır (Çalık ve Çınar, 2009). İnsan aklında nesnelerin bu düşünsel formları doğuştan mevcuttur. Düşünmenin temel ilkesi olan akıl doğrudan Tanrı tarafından gerçekleştirilmiş bir ilke ve cevher olup, idelere yönelmiş bir güçtür. İdelere yönelmek ise, aklın, ruhun bedene girmeden önce yaşadığ İdealar dünyasındaki hayatında görmüş olduğu idelerin -ki bunlar nesneler dünyasında insan aklında belirsiz bir şekilde yer alır- yaşantılarla hatırlanmasıdır (Derbeder, 2007). Öyleyse İdealizme göre öğrenmek, yaşayarak akılda belirsiz olarak var olan ideleri hatırlamaktır. Nesneler dünyasından duyularla elde edilen bilgi gerçek ve mutlak olamaz. Çünkü bu dünya sadece bir yansımadır, gelip geçicidir. Saf, soyut düşünce olan ideler ise gerçektir ve ebedidir. İdealizmde dile getirilen bu düşünceler, maddeyi insan aklının bir ürünü sayan Rasyonalizmde de görmek mümkündür (Ergün, 2015).

Aristo ile özdeşleşen Realizmde ise, İdealizmde olduğu gibi iki dünya ayrımı yoktur. Yani varlıklar insan bilincinin dişında ona bağlı olmadan gerçekte vardırlar. Nesneler, gerçeğin bir görüntüsü ya da yansıması değil gerçeğin ta kendileridir. İdealizmdeki ide ve nesne ayrımı yerine Realizmde ideler gerçek varlıkların içine "öz" olarak yerleştirilmiştir. Yani her varlık madde ve formdan oluşur. Madde ve formdan oluşan nesneler insan bilincinden bağımsız olarak vardır. İki dünya ayrımı olmadığı için Realizmde, İdealizmde olduğu gibi insanın diğer bir dünyadan doğuştan getirdiği bir bilgi de yoktur. Dolayısıyla bilginin kaynağı akıl değil, gerçek olan dış dünyadır (Keleş, 2013). Akıl dış dünyadan aldığımız duyumlar çerçevesinde şekillenir. Yani İdealizmde olduğu gibi dış dünyayı akıl değil, dış dünya aklı şekillendirir (Ergün, 2015). Bilginin kaynağı olan dış dünyadaki bilgilere, duyularla ve akılla ulaşılır. Duyularla elde edilen bilgi akıl süzgecinden geçirilir ve rasyonel bilgiye dönüştürülerek tamamlanır. Dış dünyanın bilgisine, deney, gözlem ve akılla ulaşılır (Aytaç, 2020). Bu bir anlamda öğrenme sürecini de tarif eder. Yani öğrenme deney, gözlem ve akıl yoluyla dış dünyadaki gerçekliğin bireye transfer edilmesidir (Johansen, 1991). Realizme göre, eğer insan aklı, dış dünyaya göre şekilleniyorsa öğrenmeyi tanımlamak için edilgen insan zihnini incelemek yerine, tıpkı Davranışçı Öğrenme Kuramlarında olduğu gibi, insanın gözlenebilir davranışlarındaki değişim incelenmelidir (Johansen, 1991). 
Pragmatizm, İdealizm ve Realizmin ortaya koyduğu bilgi felsefelerini eleştirmiş, onların bilginin kaynağını insan deneyimlerinden bağımsız olarak akıl ya da dış dünya olarak göstermelerine karşı çıkmıştır. Örneğin İdealizmin gerçekliği maddenin ötesinde tinsel bir gerçeklik olarak ortaya koymasını, mutlak gerçek bilginin doğuştan insan aklında var olduğunu ileri sürmesini ve bu bilgiye sezgi, hatırlama gibi zihinsel yollarla aklı kullanarak ulaşılabileceğini iddia etmesini eleştirir. Aynı şekilde gerçekliğin ve bilginin nesneler dünyasında olduğuna, bu bilgiye deney, gözlem ve akılla yani duyumsama ve soyutlama yoluyla ulaşılabileceğine dair Realizmin ileri sürdüğü görüşlere de karşı çıkar. Pragmatizme göre gerçeklik ve bilgi insan deneyimleri yoluyla oluşturulur. Yani insan deneyimleriyle kendi öznel bilgisini oluşturur (Sözer ve Sel, 2015). İnsan kendi deneyimleriyle gerçekliğe ve bilgiye ulaşan biyo-kültürel ve toplumsal bir varlıktır (Sönmez, 2015). Bilginin kaynağı ne tek başına akıl ya da zihin, ne de dış dünyadır. Bilgi insan zihniyle dış dünya arasında güçlü bir bağ kurarak yaşantılar ve deneyimlemelerle oluşturulur ki bu bir anlamda öğrenmenin de tanımıdır.

Buraya kadar kısaca özetlediğimiz bu felsefi akımların, bilginin kökeni ve kaynağı, niteliği, nesnelliği gibi hususlarda çok farklı görüşler ileri sürdüğünü, bu görüşlerin de farklı öğrenme tanımlarına neden olduğunu görebilmekteyiz. Literatür incelendiğinde öğrenmenin en yaygın tanımının "yaşantı ürünü kalıcı izli davranış değişikliği" olduğu görülmektedir (Demirel, 2003). Aslında tanımda yer alan "yaşantı ürünü" kavramı bilginin oluşturulmasında insan deneyimlerini ön plana çıkaran Pragmatizm ve onu temel alan Yapılandırmacı yaklaşımdan, "kalıc izli" kavramı akıl veya zihni bilginin kaynağ 1 ve işlendiği yer olarak gören İdealizm, Rasyonalizm ve onu temel alan Bilişsel öğrenme kuramlarından, "davranış değişikliği" kavramının ise zihinden bağımsız ölçülebilir ve gözlenebilir nesnel bilgiden bahseden Realizm, Empirizm ve onu temel alan Davranışçı öğrenme kuramlarından geldiği görülmektedir. Yani söz konusu öğrenme tanımı farklı felsefe ve kuramların görüşlerinin birleştiği eklektik bir tanımdır. Tek bir felsefe ya da kuramı esas alan bir tanım yapmak oldukça güçtür.

Farklı felsefi akımların bilgi felsefesi altındaki düşünceleri birbirlerinden farklıysa, bu durum da farklı öğrenme tanımlarının oluşmasına sebep o-luyorsa, öğretmen ya da öğrencilerin öğrenme ya da öğretim yaklaşımları ile epistemolojik inançları arasında bir ilişki kurulabilir mi? Literatür 
incelendiğinde, bu konuya ilişkin çeşitli araştırmaların olduğunu görebiliyoruz. Ancak bu araştırmalara geçmeden önce, epistemolojik inançlar ve öğrenme yaklaşımları konularını incelemekte fayda olduğu düşünülmektedir.

Gelişimsel bir süreç olarak tanımlanan epistemolojik inançlara ilişkin psikoloji alanındaki çalışmalar 1950'li yıllara kadar uzanmaktadır. O günden günümüze kadar araştırmacılar epistemolojik inançların gelişimine yönelik olarak birçok model ortaya koymuştur. Bu araştırmalar genellikle üç ana başlıkta yoğunlaşmıştır. Bir grup araştırmacı, bireylerin eğitim deneyimlerini nasıl yorumladıkları, kadınların bilme yollarını ve cinsiyet gözetmeksizin genel olarak bilme yollarını araştırdılar. İkinci bir grup araştırmacı ise epistemolojik inançların akıl yürütme süreçlerini nasıl etkilediğine ilişkin araştırmalar yaptılar. Üçüncü grupta yer alan araştırmacılar ise epistemolojik inançların akademik görevler ve öğrenmeyle ilişkisi üzerinde durdular (Hofer ve Pintrich, 1997).

İlk araştırmalarla birlikte epistemolojik inançlar, eğitimcilerin ve psikologların giderek ilgilendikleri bir konu haline gelmiştir. "Bireylerin nasıl bildiği, bilme hakkında sahip oldukları teori ve inançlar ve bunların düşünme ve akıl yürütme gibi bilişsel süreçlerdeki yeri" gibi konular sıklıkla araştırılmaya başlanmıştır (Hofer ve Pintrich, 1997). Bu araştırmalar neticesinde epistemolojik inanç, kişilerin bilginin doğasına ilişkin kişisel inançları olarak tanımlanabilir. Burada bilginin doğasından kastedilen aslında kişinin nasıl bildiği, bilginin kaynağının neresi olduğu, bilginin kesin ve nesnel mi yoksa öznel mi olduğu, bilginin yapısının ne olduğu, bilginin öğrenilme hızı ve kontrolünün nasıl olduğudur. İşte epistemolojik inanç, sayılan tüm bu konulara ilişkin bireylerin gelişimsel bir süreç içerisinde sahip oldukları kişisel inançlarıdır (Schommer, 1990).

Epistemolojik inanç ile ilgili araştırmalarla ortaya konan teori ve modeller, bilginin mutlak ya da değişebilir olup olmadığı, bilginin hangi kaynaktan elde edildiği, bilginin oluşturulabilir mi yoksa edinilir mi olduğu ve bilginin basit ya da karmaşık olduğu ile ilgili inançlar üzerinde durmuşlardır (İçen ve Akpınar, 2016). Schommer (1990); kendinden önce yapılan bir takım araştırmaları sentezleyerek (Perry, 1968; Ryan, 1984; Schoenfeld, 1983) epistemolojik inançları, her biri gelişimsel bir süreç olan ve beş aşamadan oluşan kişisel epistemolojik inanç sistemi olarak tanımlamıştır. Buna göre; (a) basitten karmaşığa doğru gelişen bilginin yapısına ilişkin inançlar, (b) kesinden 
değişebilir olmaya doğru gelişen bilginin değişimine ilişkin inançlar, (c) bir uzman ya da otoriteden edinilebilirden mantık ve kanttlar yoluyla oluşturulabilire doğru gelişen bilginin kaynağına ilişkin inançlar, (d) hızlı öğrenilebilirden süreç içerisinde öğrenilebilire doğru gelişen öğrenme hızına ilişkin inançlar ve (e) öğrenmenin doğuştan getirilen bir yetenek olduğundan sonradan geliştirilebileceğine doğru gelişen öğrenme yetisine ilişkin inançlardır. Dweck ve Leggett 'in (1988) öğrenme yeteneği hakkındaki inancın öğrenme süreci için kritik olduğu fikri Schommer' in 1990'da oluşturduğu gelişen epistemolojik inanç sistemine önemli bir destek sağlamıştır. Zira bu çalışmada, zor bir görevle karşlaş̧tıklarında öğrenme yeteneğinin doğuştan getirildiği ve değişmeyeceği inancına sahip çocukların çaresiz kaldıkları, öğrenme yeteneğinin gelişebileceğine inanan çocukların ise bu zor görev karşısında farklı stratejiler denedikleri ortaya konmuştur (Schommer-Aikins, 2004). Jehng, Johnson ve Anderson (1993), Amerika'da 386 üniversite öğrencisi üzerinde yürüttükleri çalışmada öğrencilerin epistemolojik inançlarını Schommer'inki (1990) gibi beş faktör altında toplamışlardır. Bunlar; belirli bilgi, her şeyden sorumlu otorite, doğuştan getirilen yetenek, hızlı öğrenme ve düzenli süreçtir. Qian ve Alvermann (1995) ise epistemolojik inançlar ile öğrenilmiş çaresizlik arasındaki ilişkiyi inceledikleri araştırmada gerçekleştirdikleri faktör analizi ile epistemolojik inançları üç faktör altında toplamışlardır. Bunlar; basit-kesin bilgi, hızlı öğrenme ve doğuştan yetenektir.

Schommer (1990, 1994), bireylerin sahip oldukları inançların farklı ve karmaşık düzeyde olabileceğini, zira gelişimsel bir süreç olan ve beş ayrı faktörden oluşan inançlar sistemindeki her bir faktörün birbirinden bağımsız olduğunu, bu faktörlerin birbirini izleyen ardışık aşamalar olmadığını, inanç faktörlerinin her birinin öğrenmeyi ayrı ayrı etkileyebileceği gibi, farklı faktörlerin bileşim ve kombinasyonları da öğrenmeyi farklı şekilde etkileyebilir. Ancak genel olarak bireylerin gelişmemiş/olgunlaşmamış ve gelişmiş/olgunlaşmış inanç eğilimlerinin olabileceği vurgulanmıştır. Gelişmemiş/olgunlaşmamış epistemolojik inanca sahip öğretmenlerin, bilgi sahibinin ve otoritenin öğretmen olduğunu, bilginin değişmez olduğunu, öğrencilerin iyi dizayn edilmiş materyaller ve sunumlar yoluyla hızlı bir şekilde öğrenebileceklerini ve yine öğrencilerin kendi yetenek seviyeleri kadar öğrenebileceğini kabul ederken, gelişmiş/olgunlaşmış (yapılandırmacı-constructivist) inanca sahip öğretmenlerin ise öğrencilerin okudukları ve duyduklarına 
eleştirel gözle baktıkların ve bilginin farklı kaynaklarda olduğunu, öğrenmenin karmaşık ve süreç içerisinde gerçekleştiğini ve öğrenci tarafından yapılandırıldığını kabul etmektedirler (Howard, McGee, Schwartz ve Purcell, 2000).

Eğitim ve psikoloji alanında inanç sistemlerinin çeşitli değişkenler üzerindeki etkisi geniş çapta kabul edilmiştir. Örneğin öğrencilerin başarılı ya da başarısız olacaklarına dair inançlarının sonraki motivasyon ve çabalarını etkilediği ortaya konmuştur (Dweck, 1986). Benzer şekilde öğrencilerin okuma ve okuma metinlerine ilişkin inançlarının onların bilgiyi işleme süreçlerini etkilediği ortaya konmuştur (Garner ve Alexander ,1994). Dolayısıyla genel olarak bireylerin inançları bir bağımsız değişken olarak birçok değişken üzerinde etkilidir. Epistemolojik inançlarla ilgili olarak da, yani epistemoljik inançların çeşitli değişkenler üzerindeki etkisini araştıranbirçok çalışma mevcuttur. Kişilerin sahip oldukları epistemolojik inançların onların anlama ve öğrenmelerini etkilediği (Müller, Rebmann, ve Liebsch, 2008), yine bu inançların öğretmenlerin sınıf içi öğretim etkinlik ve uygulamalarını etkilediği (Lee, Zhang, Song ve Huang, 2013), öğrencilerin sahip oldukları epistemolojik inançlarla başarı düzeyleri arasında anlamlı ilişki olduğu (Schommer-Aikins, Mau, Brookhart ve Hut`ter, 2000), epistemolojik inançların cinsiyete göre değiştiği (Eroğlu ve Güven, 2006), gelişmiş epistemolojik inançlara sahip olan öğrencilerin akademik başarılarının diğer öğrencilere göre daha yüksek olduğu (Ryan, 1984; Schommer, Crouse, Rhodes, 1992) bu çalışmalara birer örnektir. Akademik başarının açıklanmasında önemli değişkenlerden biri olan öğrencilerin ders çalışma yaklaşımları ile epistemolojik inançları arasında anlamlı bir ilişki olabilir mi? Bu konuyla ilgili alanyazındaki araştırmaların sonuçlarına geçmeden önce öğrencilerin ders çalışırken kullandıkları öğrenme yaklaşımları konusunu yine literatüre göre tartışalım.

Biggs'e (1999) göre öğrencilerin ne amaçla öğrendikleri önemlidir. Bu noktada iki grup öğrenciden söz edilebilir. Bunlardan birincisi çalıştığı konuyu, anlamaya, yorumlamaya, anlamlandırmaya ve konuyu tüm boyutlarıyla zihninde yapılandırmaya çalışanlardır. İkincisi ise konuyu tam olarak zihninde yapılandırarak anlamaktan çok ezberlemeye odaklananlardır. Dolayısıyla birisinde amaç anlamak iken diğerinde amaç ezberlemektir. Marton ve Säljö (1976a), İsveç'te bir grup üniversite öğrencisinin kendilerine verilen okuma pasajlarını ne tür bir öğrenme yaklaşımı kullanarak 
çalıştıklarını nitel yöntemlerle araştırmışlar ve sonuç olarak öğrencilerin okuma parçalarında verilen bilgiyi zihinlerinde derin ya da yüzeysel olarak işlediklerini ortaya koymuşlardır. Yine Marton ve Säljö (1976b) tarafından yapılan başka bir çalışmada, soru şekilleri ile öğrenme yaklaşımları arasındaki ilişki araştırılmış; olguları hatırlamaya yönelik sorular sorulduğunda öğrencilerin yüzeysel bir yaklaşımı, anlam aramaya yönelik sorularda ise derinlemesine yaklaşımı benimsedikleri tespit edilmiştir. Öğrencilerden beklenen görev, öğrenme yaklaşımı tercihlerini değiştirmiştir. Öğrenenlerin ders çalışırken yani öğrenme işini gerçekleştirirken öğrenmeye ilişkin önceden oluşturdukları kavramsal anlayış, öğrenmeyi hangi amaçla yaptıkları, belirledikleri bu amaçlar için ne tür öğrenme stratejileri seçtikleri ve kullandıklarını önemlidir (Prosser, Trigwell, 1999). Yılmaz ve Orhan (2011) bazı öğrencilerin tam olarak anlamak için ders çalışırken bazı öğrencilerin ise sadece dersi geçmek için çalıştıklarını dile getirmişlerdir.

Derinlemesine öğrenme yaklaşımı; ders çalışma görevini anlayarak yapma ihtiyacından kaynaklanan iç motivasyonunun bir bileşenidir (Biggs, 2001; Biggs ve Tang, 2007). Bu yaklaşımı benimseyen öğrenci, öğrenmek için en uygun bilişsel startejiyi belirler, metnin altında yatan anlama, ana fikirlere odaklanır. Detayları inceler, bir araya getirir ve büyük resmi göremeye çalışır (Biggs ve Tang, 2007). Hipotezler oluşturup bunları test edebilir, metin içerisindeki içerikler arasında bağlantıları bulmaya çalışırlar, zihinlerinde benzetimler ve metaforlar oluştur, çalıştıkları konuları önceki bilgileriyle ilişkilendirmeye çalışırlar. Bütün bunları yapabilmeleri için gerekli olan şartlar ise, niyet ve içsel motivasyon, ön bilgiyi sahip olma, öğrenmeye ilişkin önceki deneyimlerinden hareketle oluşturdukları kavramsal anlayış ve anlayarak çalışma tercih ve becerileridir (Biggs ve Tang, 2007). Yüzeysel öğrenme yaklaşımı ise, dersin gereklerini asgari düzeyde ve düşük bir çaba ile yerine getirebilmedir. Öğrenme bir görevdir ve aşılması gereken bir engeldir. Amaç düşük düzeyde bilişsel etkinliklerle engeli aşmak ve görevi tamamlamaktır (Biggs ve Tang, 2007).

Akademik başarı ile öğrencilerin ders çalışma ve etkili öğrenme yaklaşımları arasında ilişki olduğu, akademik başarı ya da başarısızlığın nedenlerinin başında ders çalışma ve öğrenme yaklaşımlarının geldiğine dair literatürde birçok araştırma mevcuttur (Bahar ve Okur, 2018; Özer ve Anıl, 2011; Dural, 2008; Subaşı, 2000). Alanyazına bakıldığında benimsenen ders çalışma 
yaklaşımları ile akademik başarı arasında anlamlı ilişkiler olduğu, derinlemesine öğrenme yaklaşımına sahip olma ile akademik başarı arasında pozitif, yüzeysel öğrenme yaklaşımına sahip olma ile akademik başarı arasında negatif yönlü ilişki olduğuna dair bazı araştırmalar mevcuttur (Çetin, 2016; Olpak ve Korucu 2014). Bunun dişında ders çalışırken kullanılan öğrenme yaklaşımının cinsiyete göre değişmediği (Ellez ve Sezgin, 2002; Yıldız, 2010) yönünde araştırmaların yanında cinsiyete göre değiştiğine dair araştırmalar da vardır (Beşoluk ve Önder, 2010; Miller, Finley ve McKinley, 1990).

Buraya kadar epistemolojik inançlar ve ders çalışma yaklaşımları konusu literatüre dayalı olarak açıklanmıştır. Epistemolojik inançlar ile öğrenme etkileşimi ile ilgili olarak da alanyazında bazı araştırmalara rastlamaktayız. Oğuz (2008), öğretmen adaylarının epistemolojik inançlarının onların öğrenim ve öğretim ile ilgili düşüncelerini şekillendirdiğini ortaya koyarken, Eick (2000) aynı durumun Fen Bilgisi öğretmenleri için de geçerli olduğu sonucuna ulaşmıştır. Gill ve arkadaşları (2004) epistemolojik inanışlarının Matematik öğretmenlerinin öğretim yaklaşımlarından etkilendiğini, Ravindran ve arkadaşları (2005) ise epistemolojik inançlar ile öğrenme amaçları ve süreçleri arasında önemli bir ilişki olduğunu ortaya koymuşlardır. Bununla birlikte literatür incelendiğinde epistemolojik inançlar ile ders çalışma yaklaşımları arasındaki ilişkiyi araştıran sınırlı sayıda çalışma olduğu gözlenmekte olup bu çalışmanın amacl; öğretmen adaylarının epistemolojik inançları ile ders çalışma yaklaşımların belirlemek ve buradan hareketle bu iki değişken arasında anlamlı bir ilişkinin olup olmadığını ortaya koymaktır. $\mathrm{Bu}$ amaç çerçevesinde araştırmanın alt problemleri aşağıda yer almaktadır.

1. Öğretmen adaylarının epistemolojik inançları nasıldır?

2. Öğretmen adaylarının epistemolojik inançları çeşitli değişkenlere göre farklılık göstermekte midir?

3. Öğretmen adaylarının ders çalışma yaklaşımları nasıldır?

4. Öğretmen adaylarının ders çalışma yaklaşımları çeşitli değişkenlere göre farklılık göstermekte midir?

5. Öğretmen adaylarının epistemolojik inançları ile ders çalışma yaklaşımları arasında anlamlı bir ilişki var mıdır? 


\section{Yöntem}

\section{Araştırma Modeli}

Öğretmen adaylarının epistemolojik inançlarının ve ders çalışma yaklaşımlarının incelendiği bu betimsel çalışmada tarama (survey) modeli kullanılmıştır. Karasar (1999) genel tarama modellerini, geniş ve içerisinde çok sayıda elemandan müteşekkil evren hakkında genel bir yargıya varmak için evrenin tamamı ya da ondan seçilecek örnek veya örneklem üzerinden yapılan tarama düzenlemeleri olarak tanımlamaktadır. Dolayısıyla tarama modellerinde evren ve örneklem vardır ve örneklemin evreni temsil etmesi, sonuçların genellenebilirliği açısında son derece önemlidir (Kuş, 2009). Bu çalışmada kişisel görüş ve ifadelere göre inanç ve yaklaşımlara ilişkin araştırma soruları bulunduğu için tarama modeli tercih edilmiştir.

\section{Çalışma Grubu}

Bu araştırmanın evrenini 2018-2019 eğitim-öğretim yılında Sivas Cumhuriyet Üniversitesi Eğitim Fakültesinde öğrenim görmekte olan öğretmen adayları oluşturmaktadır. Çalışma grubu ise farklı öğretmenlik bölümlerinde son sınıfta öğrenim gören öğretmen adaylarından oluşmakta olup, Tablo 1'de çalışma grubunun öğrenim gördükleri programa ve cinsiyetlerine göre dağılımını gösteren bilgiler yer almaktadır.

Tablo 1. Çalışma grubunun öğrenim görülen programlara ve cinsiyete göre dă̆ılımı

\begin{tabular}{|c|c|c|c|c|}
\hline & & \multicolumn{2}{|c|}{ Cinsiyet } & \multirow[b]{2}{*}{ Toplam } \\
\hline & & Kadın & Erkek & \\
\hline \multirow{5}{*}{$\begin{array}{l}\text { Öğrenim Görülen Pro- } \\
\text { gramlar }\end{array}$} & PDR & 25 & 14 & 39 \\
\hline & Fen Bilgisi Öğretmenliği & 20 & 7 & 27 \\
\hline & Sınıf Öğretmenliği & 17 & 5 & 22 \\
\hline & Okul Öncesi Öğretmenliği & 42 & 9 & 51 \\
\hline & Türkçe Öğretmenliği & 27 & 12 & 39 \\
\hline Toplam & & 131 & 47 & 178 \\
\hline
\end{tabular}

Tablo 1 incelendiğinde çalışma grubundaki öğretmen adaylarının \%74'ünün kadın, \%26'sının erkek olduğu görülmektedir. Öğretmen adayla- 
rının \%22'sinin PDR, \%15'inin Sınıf Öğretmenliği, \%12'sinin Sınıf Öğretmenliği, \%29'unun Okul Öncesi Öğretmenliği ve \%22'sinin Türkçe Öğretmenliği bölümlerinde öğrenim gördükleri görülmektedir.

\section{Veri Toplama Araçları}

Öğretmen adaylarının epistemolojik inançlarını betimlemek için Conley ve arkadaşları (2004) tarafından geliştirilen; çeviri, uyarlama (üniversite öğrencileri için), geçerlik ve güvenirlik çalışması Akçay, Gezer ve Akçay (2016) tarafından yapılmış olan "Epistemolojik İnanç Ölçeği” kullanılmıştır. Öğretmen adaylarının ders çalışma yaklaşımlarını betimlemek için ise, Biggs, Kember ve Leung (2001) tarafından geliştirilen, çeviri, uyarlama, geçerlik ve güvenirlik çalışması Yılmaz ve Orhan (2011) tarafından yapılan "Ders Çalışma Yaklaşımı Ölçeği" kullanılmıştır. Ayrıca çalışma grubunda yer alan öğretmen adaylarının kişisel niteliklerini ortaya koymak amacıyla araştırmacılar tarafından geliştirilen "Kişisel Bilgi Formu” kullanılmıştır.

Epistemolojik İnanç Ölçeği (ĖIÖ): Conley ve arkadaşları (2004) tarafından geliştirilen, Akçay, Gezer ve Akçay (2016) tarafından uyarlama çalışması yapılan "Epistemolojik İnanç Ölçeği” öğretmen adaylarının epistemolojik inançlarını belirlemeyi amaçlamaktadır. Orijinal ölçek 26 maddeden oluşmakta olup, 5'li Likert sisteme göre derecelendirilmiştir (1= tamamen katılmıyorum, 5=tamamen katılıyorum arasında). Orijinal ölçek 4 alt boyuttan oluşmaktadır. Bunlar; "bilginin kaynağı, bilginin gerekçelendirilmesi, bilginin değişmezliği, bilginin gelişimidir". Orijinal ölçeğin Akçay, Gezer ve Akçay (2016) tarafından uyarlanmış hali de yine 5'li likert tipi derecelendirmeli 19 maddeden oluşmaktadır. Uyarlama çalışmaları sonunda ölçek, orijinalinden farklı olarak 3 alt boyuttan oluşmaktadır. Bu alt boyutlar; "bilginin gerekçelendirilmesi (madde numaraları: 18, 11, 19, 15, 9, 7, 4), bilginin kaynağı/değişmezliği (madde numaraları: $5,1,13,2,8,12$, 16) ve bilginin gelişimidir (madde numaraları: 3, 6, 10 14, 17)." Ölçeğin tümüne ait Cronbach Alfa güvenirlik katsayısı. 853 olarak belirlenmiştir.

Ders Çalışma Yaklaşımı Ölçeği (DÇYÖ): Biggs, Kember ve Leung (2001) tarafından geliştirilen, çeviri, uyarlama, geçerlik ve güvenirlik çalışması Yılmaz ve Orhan (2011) tarafından yapılan "Ders Çalışma Yaklaşımı Ölçeği" 
öğretmen adaylarının ders çalışma yaklaşımlarını ortaya koymayı amaçlamaktadır. Orijinal ölçek, 20 maddeden oluşmakta olup, 5'li Likert sisteme göre derecelendirilmiştir (1=benim için asla geçerli değil ya da nadiren geçerli, 5=benim için her zaman ya da hemen hemen her zaman geçerli). Orijinal ölçek 2 boyut ve her boyut kendi içerisinde 2 alt boyuttan oluşmaktadır. Birinci boyut "derin yaklaşım" olup bu boyut kendi içerisinde "derin motivasyon ve derin strateji" olmak üzere iki alt boyuta ayrılmaktadır. İkinci boyut ise "yüzeysel yaklaşım" olup bu boyut da yine kendi içerisinde "yüzeysel motivasyon ve yüzeysel strateji" olmak üzere iki alt boyuta ayrılmaktadır. Orijinal ölçeğin Yılmaz ve Orhan (2011) tarafından uyarlanmış hali de yine 20 maddeden oluşmaktadır. Uyarlama çalışmaları sonunda ölçek, orijinalinde olduğu gibi 2 boyut ve her boyut kendi içerisinde 2 alt boyuttan oluşmaktadır. Derin yaklaşım boyutunu; 1, 2, 5, 6, 9, 10, 13, 14, 17 ve 18. maddeler, yüzeysel yaklaşım boyutunu ise; $3,4,7,8,11,12,15,16,19$ ve 20. maddeler temsil etmektedir. Ölçeğin tümüne ait Cronbach Alfa güvenirlik katsayısı. 76 olarak belirlenmiştir.

Kişisel Bilgi Formu: Öğretmen adaylarının demografik bilgilerini ve araştırma kapsamında yer alan değişkenleri ortaya koymak için araştırmacılar tarafından hazırlanmıştır. Formda araştırmaya katılan öğretmen adaylarının; cinsiyetleri, öğrenim gördükleri bölümler ve kitap okuma sıklıklarına ilişkin bilgiler yer almaktadır.

\section{Verilerin Çözümü ve Analizi}

Araştırmanın istatistiksel çözümlemeleri SPSS13.0 kullanılarak yapılmıştır. Araştırmanın birinci ve üçüncü alt problemine ilişkin betimsel istatistikler yüzde ve frekans olarak çözümlenmiştir. Diğer alt problemlere ilişkin verilerin çözümlenmesinde öncelikle verilerin normal dağılım gösterip göstermediğine bakılmış ve verilerin normal dağılım göstermediği belirlenmiştir. Araştırmanın ikinci ve dördüncü alt problemleri kapsamında toplanan ve normal dağılım göstermeyen verilerden iki değişkenli durumlarda gruplar arasında anlamlı bir farkın olup olmadığını belirlemek için non-parametrik Mann Whitney U, ikiden fazla değişkenli durumlarda ise Kruskal Wallis testleri (varyansların homojenliği testinde varyansların homojen olmadığı belirlendiği için post hoc Games-Howell testi uygulanmıştır) kullanılmıştır. 
Araştırmanın beşinci alt problemine ilişkin toplanan verilerin çözümlenmesi için ise Spearman korelasyon testi kullanılmıştır.

\section{Bulgular}

Bu bölümde, araştırmanın alt problemlerine ilişkin veri analizlerine ve elde edilen bulgulara ve bulgulara yer verilmiştir. Araştırmanın birinci alt probleminde öğretmen adaylarının epistemolojik inançları araştırılmış olup, öğretmen adaylarının "Epistemolojik İnanç Ölçeği”" ne verdikleri cevapların ölçek alt boyutları ve tamamındaki medyan ve standart sapmalarına ilişkin veriler Tablo 2.'de verilmiştir.

Tablo 2. Öğretmen Adaylarının Epistemolojik İnanç Boyutlarının Betimsel Analizi

\begin{tabular}{llll}
\hline Alt Boyutlar & N & Medyan & Ss. \\
\hline Bilginin gerekçelendirilmesi & 178 & 4 &, 67 \\
Bilginin kaynağ/değişmezliği & 178 & 2 &, 78 \\
Bilginin gelişimi & 178 & 4 &, 68 \\
Toplam & 178 & 4 &, 58 \\
\hline
\end{tabular}

Tablo 2'de yer alan, ölçeğin tamamından ve ölçeğin alt boyutlarından alınan medyan puanlarının (ölçeğin tamamı ve alt boyutlarındaki puanlar normal dağılmadığı için medyan puanları kullanılmıştır) yüksekliği, gelişmiş/olgunlaşmış epistemolojik inanca sahip olmayı, puanların düşüklüğü ise gelişmemiş/olgunlaşmamış epistemolojik inanca sahip olmayı işaret etmektedir. Buradan hareketle Tablo 2 incelendiğinde öğretmen adaylarının "bilginin gerekçelendirilmesi (medyan=4)", "bilginin gelişimi (medyan= 4)" alt boyutlarında ve ölçeğin tamamında (medyan=4) \%80 düzeyinde epistemolojik inanca sahip oldukları ve bu inancın gelişmiş/olgunlaşmış inanç seviyesinde olduğu, "bilginin kaynağı/değişmezliği (medyan $=2$ )" alt boyutunda ise $\% 40$ düzeyinde inanca sahip oldukları ve bu inancın gelişmemiş/olgunlaşmamış inanç seviyesinde olduğu söylenebilir. Yani öğretmen adayları genel olarak, bilginin sorgulanarak gerekçelendirilmesi gerektiğine ve bilginin değişip gelişebileceğine dair bir inanca sahipken, bilginin kaynağının belirli kaynaklar ve belirli kişiler olabileceğini ve bunun değişmeyeceğine dair bir inanca sahiptirler.

Araştırmanın ikinci alt probleminde, öğretmen adaylarının epistemolojik inançlarının çeşitli değişkenlere (cinsiyet, öğrenim görülen bölüm ve kitap 
okuma sıklı̆̆) göre anlamlı bir farklılık gösterip göstermeyeceği araştırılmıştır. Öğretmen adaylarının epistemolojik inançlarının cinsiyete göre farklılaşıp farklılaşmadığını gösteren Mann Whitney U testi sonuçları, Tablo 3'de verilmiştir.

Tablo 3. Öğretmen Adaylarının Epistemolojik İnançlarının Cinsiyete Göre Mann Whitney U Testi Sonuçları

\begin{tabular}{llllll}
\hline Alt Boyutlar & Cinsiyet & $\mathbf{N}$ & S.Ort. & $\mathbf{Z}$ & p \\
\hline \multirow{2}{*}{ Bilginin gerekçelendirilmesi } & Kadın & 131 & 90,44 & \multirow{2}{*}{, 408} & \multirow{2}{*}{, 683} \\
& Erkek & 47 & 86,88 & & \\
\multirow{2}{*}{ Bilginin kaynağı/değişmezliği } & Kadın & 131 & 88,35 & \multirow{2}{*}{, 498} & \multirow{2}{*}{, 618} \\
& Erkek & 47 & 92,70 & & \\
\multirow{2}{*}{ Bilginin gelişimi } & Kadın & 131 & 87,48 & \multirow{2}{*}{, 878} & \multirow{2}{*}{, 380} \\
\hline
\end{tabular}

$p<0,05$ düzeyinde anlaml

Tablo 3 incelendiğinde öğretmen adaylarının cinsiyete göre ölçeğin tamamindan ve her bir alt boyutunda aldıkları puanların ortalamaları arasında anlamlı bir fark olmadığ 1 görülmektedir $(\mathrm{p}>0,05)$. Bununla birlikte ölçeğin genelinde erkek öğrencilerin epistemolojik inanç puanları (Xort=90,90) kız öğrencilerin epistemolojik inanç puanlarına (Xort= 89,00) göre daha yüksektir. Alt boyutlara göre sonuçlara bakıldığında; "bilginin gerekçelendirilmesi" alt boyutunda kız öğrencilerin puanlarının (Xort= 90,44) erkek öğrencilerin puanlarına (Xort= 86,88) göre daha yüksektir. "Bilginin kaynağı/değişmezliği" alt boyutunda erkek öğrencilerin puanları (Xort= 92,70) kız öğrencilerin puanlarına (Xort= 88,35) göre daha yüksektir. "Bilginin gelişimi" alt boyutunda da yine erkek öğrencilerin puanları (Xort=95,12) kız öğrencilerin puanlarına (Xort= 87,43$)$ göre daha yüksektir.

Öğretmen adaylarının epistemolojik inançlarının öğrenim gördükleri bölümlere göre farklılaşıp farklılaşmadığını gösteren Kruskal Wallis testi sonuçları Tablo 4' de verilmiştir.

Tablo 4 incelendiğinde öğretmen adaylarının epistemolojik inançlarının ölçeğin tamamında ve "bilginin gerekçelendirilmesi ile bilginin kaynağı/değişmezliği" alt boyutlarında adayların öğrenim gördükleri bölümlere göre anlamlı bir farklılık göstermediği ( $>>0,05)$, "bilginin gelişimi" alt boyutunda ise anlamlı derecede farklılık gösterdiği $(p<0,05)$ görülmektedir. Bilginin gelişimi alt boyutunda anlamlı farkın hangi gruplar arasında olduğunu belirle- 
mek için post hoc testlerinden Games-Howell testi yapılmış ve bu test sonucunda PDR bölümünde öğrenim gören öğretmen adaylarının epistemolojik inanç puanlarının Sınıf $(p=0,009<0,05)$ ve Fen Bilgisi Öğretmenliği $(p=0,033<0,05)$ bölümünde öğrenim gören öğretmen adaylarına göre anlamlı derecede yüksek çıkmıştır.

Tablo 4. Öğretmen Adaylarının Epistemolojik İnançlarının Öğrenim Gördükleri Bölümlere Göre Kruskal Wallis Testi Sonuçlarn

\begin{tabular}{|c|c|c|c|c|c|c|}
\hline $\begin{array}{l}\text { Epistemolojik İnançlar } \\
\text { Alt Boyutlar }\end{array}$ & & $\mathbf{N}$ & S.Ort. & sd & $x^{2}$ & p \\
\hline \multirow{6}{*}{$\begin{array}{l}\text { Bilginin } \\
\text { Gerekçelendirilmesi }\end{array}$} & PDR & 39 & 107,76 & & & \\
\hline & Fen Bilgisi & 27 & 80,07 & & & \\
\hline & Sinif & 22 & 86,82 & 4 & 6,658 & 0,155 \\
\hline & Okul Öncesi & 51 & 86,23 & & & \\
\hline & Türkçe & 39 & 83,56 & & & \\
\hline & Toplam & 178 & & & & \\
\hline \multirow{6}{*}{$\begin{array}{l}\text { Bilginin Kaynağı/ } \\
\text { Değişmezliği }\end{array}$} & PDR & 39 & 84,97 & & & \\
\hline & Fen Bilgisi & 27 & 104,56 & & & \\
\hline & Sinif & 22 & 92,34 & 4 & 4,116 & 0,391 \\
\hline & Okul Öncesi & 51 & 81,36 & & & \\
\hline & Türkçe & 39 & 92,64 & & & \\
\hline & Toplam & 178 & & & & \\
\hline \multirow{6}{*}{ Bilginin Gelişimi } & PDR & 39 & 110,21 & & & \\
\hline & Fen Bilgisi & 27 & 75,43 & & & \\
\hline & Sinif & 22 & 64,64 & 4 & 15,190 & $0,004^{*}$ \\
\hline & Okul Öncesi & 51 & 96,56 & & & \\
\hline & Türkçe & 39 & 83,33 & & & \\
\hline & Toplam & 178 & & & & \\
\hline \multirow{6}{*}{ Toplam } & PDR & 39 & 105,67 & & & \\
\hline & Fen Bilgisi & 27 & 88,48 & & & \\
\hline & Sinıf & 22 & 82,82 & 4 & 5,127 & ,275 \\
\hline & Okul Öncesi & 51 & 85,11 & & & \\
\hline & Türkçe & 39 & 83,55 & & & \\
\hline & Toplam & 178 & & & & \\
\hline
\end{tabular}

$p<0,05$ düzeyinde anlamlı $\left(^{*}\right)$

Bu durumda PDR bölümünde öğrenim gören öğretmen adaylarının epistemolojik inançlarının Sınıf ve Fen Bilgisi Öğretmenliği bölümünde öğrenim gören öğrencilere göre "bilginin gelişimi" alt boyutunda daha gelişmiş olduğu söylenebilir. Öğretmen adaylarının epistemolojik inançlarının kitap okuma sıklıklarına göre farklılaşıp farklılaşmadığını gösteren Kruskal Wallis testi sonuçları Tablo 5'de verilmiştir. 
Tablo 5. Öğretmen Adaylarııı Epistemolojik İnançlarıın Kitap Okuma Sıklıklarına Göre Kruskal Wallis Testi Sonuçlarn

\begin{tabular}{|c|c|c|c|c|c|c|}
\hline \multicolumn{2}{|c|}{ Epistemolojik İnançlar Alt Boyutlar } & \multirow{2}{*}{$\begin{array}{l}\mathbf{N} \\
67\end{array}$} & \multirow{2}{*}{$\frac{\text { S.Ort. }}{99,25}$} & \multirow[t]{2}{*}{ sd } & \multirow[t]{2}{*}{$x^{2}$} & \multirow[t]{2}{*}{ p } \\
\hline Bilginin & Ayda birden fazla & & & & & \\
\hline \multirow[t]{4}{*}{ Gerekçelendirilmesi } & Ayda bir & 54 & 79,97 & & & \\
\hline & Üç ayda bir & 26 & 95,56 & 4 & 7,835 & ,098 \\
\hline & Alt ayda bir & 13 & 95,65 & & & \\
\hline & Yılda bir veya az & 18 & 68,61 & & & \\
\hline Bilginin Kaynağı/ & Ayda birden fazla & 67 & 94,57 & & & \\
\hline \multirow[t]{4}{*}{ Değişmezliği } & Ayda bir & 54 & 82,18 & & & \\
\hline & Üç ayda bir & 26 & 82,94 & 4 & 3,882 & ,422 \\
\hline & Altı ayda bir & 13 & 85,50 & & & \\
\hline & Yilda bir veya az & 18 & 104,94 & & & \\
\hline \multirow[t]{5}{*}{ Bilginin Gelişimi } & Ayda birden fazla & 67 & 94,85 & & & \\
\hline & Ayda bir & 54 & 87,48 & & & \\
\hline & Üç ayda bir & 26 & 91,35 & 4 & 1,988 & ,738 \\
\hline & Altı ayda bir & 13 & 82,15 & & & \\
\hline & Yılda bir veya az & 18 & 78,28 & & & \\
\hline \multirow[t]{5}{*}{ Toplam } & Ayda birden fazla & 67 & 101,04 & & & \\
\hline & Ayda bir & 54 & 79,48 & & & \\
\hline & Üç ayda bir & 26 & 85,10 & 4 & 5,869 & 209 \\
\hline & Altı ayda bir & 13 & 82,50 & & & \\
\hline & Yilda bir veya az & 18 & 88,00 & & & \\
\hline
\end{tabular}

$p<0,05$ düzeyinde anlamlı $\left(^{*}\right)$

Tablo 5 incelendiğinde öğretmen adaylarının epistemolojik inançlarının ölçeğin tamamında ve tüm alt boyutlarda adayların kitap okuma sıklıklarına göre anlamlı bir farklılık göstermediği $(\mathrm{p}>0,05)$ görülmektedir. Diğer bir deyişle farklı sıklıkta kitap okuyan öğretmen adayları, epistemolojik inançlar açısından birbirlerinden farklılık göstermemektedir.

Araştırmanın üçüncü alt probleminde öğretmen adaylarının ders çalışma yaklaşımları araştırılmış olup, öğretmen adaylarının "Ders Çalışma Yaklaşımı Ölçeği” ne verdikleri cevapların ölçek alt boyutları ve tamamındaki aritmetik ortalama ve standart sapmalarına ilişkin veriler Tablo 6.'da verilmiştir.

Tablo 6'da, Ders Çalışma Yaklaşımı Ölçeğinin tamamından ve ölçeğin alt boyutlarından alınan medyan puanları (ölçeğin tamamı ve alt boyutlarındaki puanlar normal dağılmadığı için medyan puanları kullanılmıştır) ve standart sapma değerleri görülmektedir. Buna göre ölçeğin tamamından alınan puanlar dikkate alındığında öğretmen adaylarının ders çalışma yaklaşımlarının "derin ve yüzeysel" yaklaşımın arasında, ancak derin yaklaşıma bir miktar 
daha yakın olduğu (medyan=3) söylenebilir. Derin yaklaşım alt boyutundaki puanlara göre (medyan=3,5) öğretmen adaylarının ortanın üzerinde bir oranda (\%70) bu yaklaşıma sahip oldukları görülmektedir. Yüzeysel yaklaşım alt boyutundaki puanlara göre ise (medyan=3) öğretmen adaylarının orta oranda (\%60) bu yaklaşıma sahip oldukları söylenebilir.

Tablo 6. Öğretmen Adaylarının Ders Çalışma Yaklaşımı Boyutlarının Betimsel Analizi

\begin{tabular}{llll}
\hline Alt Boyutlar & N & Medyan & Ss. \\
\hline Yüzeysel Yaklaşım & 178 & 3 &, 86 \\
Derin Yaklaşım & 178 & 3,5 &, 77 \\
Toplam & 178 & 3 &, 55 \\
\hline
\end{tabular}

Araştırmanın dördüncü alt probleminde, öğretmen adaylarının ders çalışma yaklaşımlarının çeşitli değişkenlere (cinsiyet, öğrenim görülen bölüm ve kitap okuma sıklığı) göre anlamlı bir farklılık gösterip göstermeyeceği araştırılmıştır. Öğretmen adaylarının ders çalışma yaklaşımlarının cinsiyete göre farklılaşıp farklılaşmadığını gösteren Mann Whitney U testi sonuçları, Tablo 7'de verilmiştir.

Tablo 7. Öğretmen Adaylarının Ders Çalışma Yaklaşımlarının Cinsiyete Göre Mann Whitney U Testi Sonuçlar

\begin{tabular}{llllcc}
\hline Alt Boyutlar & Cinsiyet & $\mathbf{N}$ & S.Ort. & Z & p \\
\hline \multirow{2}{*}{ Yüzeysel Yaklaşım } & Kadın & 131 & 84,43 & $-2,196$ & \multirow{2}{*}{, $028^{*}$} \\
& Erkek & 47 & 103,64 & & \\
\multirow{2}{*}{ Derin Yaklaşım } & Kadın & 131 & 91,32 &,- 788 & \multirow{2}{*}{430} \\
\hline
\end{tabular}

$p<0,05$ düzeyinde anlamlı $\left(^{*}\right)$

Tablo 7 incelendiğinde ölçeğin tamamında ve "derin yaklaşım" alt boyutunda kadın ve erkek öğretmen adaylarının ders çalışma yaklaşımları arasında anlamlı bir farkın olmadığı ( $>>0,05)$, ölçeğin "yüzeysel yaklaşım” alt boyutunda ise erkek öğretmen adayların bu boyutta aldıkları puanların aritmetik ortalamasının, kadın öğretmen adaylarının ortalama puanlarından anlamlı derecede yüksek olduğu görülmektedir $(p<0,05)$. Buna göre erkek öğretmen adaylarının ders çalışırken kadın öğretmen adaylarına göre daha çok yüzeysel bir yaklaşımla çalıştığı söylenebilir. Öğretmen adaylarının ders çalışma yaklaşımlarının öğrenim gördükleri bölümlere göre farklılaşıp 
farklılaşmadığını gösteren Kruskal Wallis testi sonuçları Tablo 8'de verilmiştir.

Tablo 8. Öğretmen Adaylarmın Ders Çalışma Yaklaşımlarmın Öğrenim Gördükleri Bölïmlere Göre Kruskal Wallis Testi Sonuçlarn

\begin{tabular}{|c|c|c|c|c|c|c|}
\hline \multicolumn{2}{|c|}{ Ders Çalışma Yaklaşımları Alt Boyutlar } & \multirow{2}{*}{$\begin{array}{l}\mathbf{N} \\
39\end{array}$} & \multirow{2}{*}{\begin{tabular}{l|} 
S.Ort. \\
94,01
\end{tabular}} & \multirow[t]{2}{*}{$\mathrm{sd}$} & \multirow[t]{2}{*}{$x^{2}$} & \multirow[t]{2}{*}{$\mathrm{p}$} \\
\hline & PDR & & & & & \\
\hline & Fen Bilgisi & 27 & 96,89 & & & \\
\hline \multirow{3}{*}{ Yüzeysel Yaklaşım } & Sinif & 22 & 95,07 & 4 & 2,206 & 698 \\
\hline & Okul Öncesi & 51 & 85,04 & & & \\
\hline & Türkçe & 39 & 82,56 & & & \\
\hline \multirow[t]{5}{*}{ Derin Yaklaşım } & PDR & 39 & 96,09 & & & \\
\hline & Fen Bilgisi & 27 & 87,00 & & & \\
\hline & Sinif & 22 & 82,00 & 4 & 5,572 & ,233 \\
\hline & Okul Öncesi & 51 & 79,28 & & & \\
\hline & Türkçe & 39 & 102,23 & & & \\
\hline \multirow[t]{5}{*}{ Toplam } & PDR & 39 & 94,90 & & & \\
\hline & Fen Bilgisi & 27 & 95,59 & & & \\
\hline & Sinif & 22 & 87,64 & 4 & 4,754 & ,314 \\
\hline & Okul Öncesi & 51 & 76,98 & & & \\
\hline & Türkçe & 39 & 97,31 & & & \\
\hline
\end{tabular}

$p<0,05$ düzeyinde anlamlı $\left(^{*}\right)$

Tablo 8 incelendiğinde öğretmen adaylarının ders çalışma yaklaşımları arasında, öğrenim gördükleri bölümlere göre anlamlı bir fark olmadığı görülmektedir $(p>0,05)$. Öğretmen adaylarının ders çalışma yaklaşımlarının kitap okuma sıklıklarına göre farklılaşıp farklılaşmadığını gösteren Kruskal Wallis testi sonuçları Tablo 9' da verilmiştir.

Tablo 9 incelendiğinde öğretmen adaylarının ders çalışma yaklaşımlarının ölçeğin tamamında ve "yüzeysel yaklaşım" alt boyutunda adayların kitap okuma sıklıklarına göre anlamlı bir farklılık göstermediği $(\mathrm{p}>0,05)$, "derin yaklaşım" alt boyutunda ise anlamlı derecede farklılık gösterdiği $(p<0,05)$ görülmektedir. Derin yaklaşım alt boyutunda anlamlı farkın hangi gruplar arasında olduğunu belirlemek için post hoc testlerinden Games-Howell testi yapılmış ve bu test sonucunda ayda birden fazla kitap okuyan öğretmen adaylarının epistemolojik inanç puanlarının üç ayda bir kitap okuyan öğretmen adaylarına göre anlamlı derecede yüksek çıkmıştır $(p=0,046<0,05)$. Bu durumda ayda birden fazla kitap okuyan öğretmen 
adaylarının üç ayda bir kitap okuyan öğretmen adaylarına göre ders çalışırken daha çok derin yaklaşımı tercih ettikleri söylenebilir.

Tablo 9. Öğretmen Adaylarının Ders Çalışma Yaklaşımlarının Kitap Okuma Sıklıklarına Göre Kruskal Wallis Testi Sonuçlarn

\begin{tabular}{|c|c|c|c|c|c|c|}
\hline \multicolumn{2}{|c|}{ Ders Çalışma Yaklaşımları Alt Boyutlar } & \multirow{2}{*}{$\begin{array}{l}\mathbf{N} \\
67\end{array}$} & \multirow{2}{*}{$\frac{\text { S.Ort. }}{81,38}$} & \multirow[t]{2}{*}{ sd } & \multirow[t]{2}{*}{$x^{2}$} & \multirow[t]{2}{*}{$\mathrm{p}$} \\
\hline Yüzeysel Yaklaşım & Ayda birden fazla & & & & & \\
\hline & Ayda bir & 54 & 93,25 & & & \\
\hline & Üç ayda bir & 26 & 88,21 & 4 & 3,726 & ,444 \\
\hline & Altı ayda bir & 13 & 103,81 & & & \\
\hline & Yllda bir veya az & 18 & 100,00 & & & \\
\hline \multirow[t]{5}{*}{ Derin Yaklaşım } & Ayda birden fazla & 67 & 103,63 & & & \\
\hline & Ayda bir & 54 & 86,86 & & & \\
\hline & Üç ayda bir & 26 & 72,06 & 4 & 10,278 &, $036^{*}$ \\
\hline & Altı ayda bir & 13 & 86,50 & & & \\
\hline & Yilda bir veya az & 18 & 72,17 & & & \\
\hline \multirow[t]{5}{*}{ Toplam } & Ayda birden fazla & 67 & 93,91 & & & \\
\hline & Ayda bir & 54 & 90,06 & & & \\
\hline & Üç ayda bir & 26 & 73,35 & 4 & 3,830 & 429 \\
\hline & Altı ayda bir & 13 & 101,38 & & & \\
\hline & Yılda bir veya az & 18 & 86,17 & & & \\
\hline
\end{tabular}

$p<0,05$ düzeyinde anlamlı $\left(^{*}\right)$

Araştırmanın beşinci alt probleminde, Öğretmen adaylarının epistemolojik inançları ile ders çalışıma yaklaşımları arasında anlamlı bir ilişkinin olup olmadığı araştırılmıştır. Söz konusu ilişkiyi gösteren Spearman Korelasyon testi sonuçları, Tablo $10^{\prime}$ da verilmiştir.

Tablo 10: Öğretmen Adaylarnm Epistemolojik İnançlar Ölçeği (EiÖ) İle Ders Çalısma Yaklaşımı Ölçeğinin (DÇYÖ) Alt Boyutlarında Aldıkları Puanların Spearman Korelasyon Analizi Sonuçlan

\begin{tabular}{llll}
\hline $\begin{array}{l}\text { Epistemolojik İnanç- } \\
\text { lar Ölçeği Alt Boyut- } \\
\text { ları }\end{array}$ & \multicolumn{2}{c}{$\begin{array}{l}\text { Bilginin Gerekçelendiril- } \\
\text { mesi }\end{array}$} & $\begin{array}{l}\text { Bilginin Kaynğı/Değişmez- Bilginin Geli- } \\
\text { liği } \\
\text { şimi }\end{array}$ \\
\hline $\begin{array}{l}\text { Ders Çalısma Yakla- Yüzeysel } \\
\text { şmı Ölçeği Alt Boyut- Yaklaşı }\end{array}$ & $\begin{array}{l}\text {-,099 } \\
\text { Derin Yak- } \\
\text { laşım }, 152^{*}\end{array}$ &, 094 &,- 070 \\
ları &, 023 &, 075 \\
\hline
\end{tabular}

$N=178 p<0,05^{*} p<0,01^{* *}$ 
Tablo 10 incelendiğinde öğretmen adaylarının Epistemolojik İnanç Ölçeğinin "bilginin gerekçelendirilmesi, bilginin kaynağı ve bilginin gelişimi" alt boyutlarından aldıkları puanlar ile Ders Çalışma Yaklaşımı Ölçeğinin "yüzeysel yaklaşım" alt boyutundan aldıkları puanlar arasında anlamlı düzeyde bir ilişki bulunmamıştır. Yine EİÖ “bilginin kaynağı ve bilginin gelişimi” alt boyutlarından aldıkları puanlar ile DÇYÖ “derin yaklaşım” alt boyutundan aldıkları puanlar arasında da anlamlı düzeyde bir ilişki tespit edilmemiştir. Öğretmen adaylarının EïÖ “bilginin gerekçelendirilmesi” alt boyutundan aldıkları puanlar ile DÇYÖ “derin yaklaşım” alt boyutundan aldıkları puanlar arasında düşük düzeyde pozitif bir ilişki $(r h o=, 152$; , $p=043<0,05)$ olduğu belirlenmiştir. EIÖ “bilginin gerekçelendirilmesi ve bilginin gelişimi” alt boyutlarından aldıkları puanlar ile DÇYÖ “yüzeysel yaklaşım” alt boyutundan aldıkları puanlar arasında istatistiksel anlamlı olmayan negatif yönlü ilişkiden söz edilebilir.

\section{Tartışma ve Sonuç}

Araştırmanın sonunda, öğretmen adaylarının epistemolojik inançlarının gelişmiş/olgunlaşmış düzeyde olduğu ve adayların epistemolojik inançlarının cinsiyete göre anlamlı bir farklılık göstermediği ortaya çıkmıştır. Epistemolojik inancın cinsiyete göre farklılaşıp farklılaşmadığına dair yapılan çalışmaların bazılarında inancın cinsiyete göre farklılaşmadığına dair bazı bulgular mevcuttur (Chan ve Sachs, 2001; Chan, 2003; Demir, 2000; Altınkurt, Yılmaz ve Oğuz, 2012; Biçer ve diğerleri, 2013; İçen, İlgan ve Göker, 2013; Koç ve Memduhoğlu, 2017). Söz konusu bu bulgular, bu araştırmanın öğretmen adaylarının epistemolojik inançlarının cinsiyete göre farklılaşmadığı bulgusunu desteklemektedir. Bunun birlikte yine alanyazın incelendiğinde epistemolojik inançların cinsiyete göre değiştiği bulgusunu ortaya koyan araştırmalar da mevcuttur (Schommer ve Dunnel, 1994; Hofer, 2000; Kaleci, 2012; Alkın-Şahin ve diğerleri, 2014; Terzi ve diğerleri, 2015).

Araştırma sonucunda, Ders Çalışma Yaklaşımı Ölçeğinin "yüzeysel yaklaşım" alt boyutunda, erkek öğretmen adaylarının aldıkları puanların, kadın öğretmen adaylarının puanlarına göre anlamlı derecede yüksek olduğudur. Alanyazın incelendiğinde bazı çalışmalarda erkek öğrencilerin "yüzeysel yaklaşım" puanlarının kızlara göre anlamlı ölçüde yüksek olduğu tespit edilmiştir (Çuhadar, Gündüz ve Tanyeri, 2013; Dönmez, Yazıcı ve Demirez, 2016; 
Ozan, Köse ve Gündoğdu, 2012). Sözü edilen araştırma sonuçları bu araştırmanın ortaya koyduğu bulguyu desteklemektedir. Bununla birlikte bu araştırmada kadın ve erkek öğretmen adaylarının "derin yaklaşım" alt boyutunda aldıkları puanlar arasında anlamlı bir fark olmadığı belirlenmişse de literatürde bazı çalışmalarda kadın öğrencilerin derin öğrenme yaklaşımını daha çok tercih ettiklerine dair bulgular da vardır (Beşoluk ve Önder, 2010; Dönmez ve diğerleri, 2016).

Araştırmanın bir diğer bulgusu da PDR bölümünde öğrenim gören öğretmen adaylarının "bilginin gelişimi" alt boyutunda aldıkları puanların Sınıf Öğretmenliği ve Fen Bilgisi Öğretmenliği bölümünde öğrenim gören öğretmen adaylarına göre anlamlı derecede yüksek olduğudur. Kıralp, Şahin ve Dinçyürek (2008) tarafından yapılan çalışmada PDR öğrencilerinin epistemolojik inançlarının gelişmiş/olgunlaşmış düzeyde olduğu belirlenmiştir ki bu sonuç PDR bölümünde öğrenim gören öğretmen adaylarının "bilginin gelişimi" alt boyutunda Sınıf ve Fen Bilgisi bölümlerinde öğrenim gören öğretmen adaylarına göre daha gelişmiş bir epistemolojik inanca sahip oldukları bulgusunu desteklemektedir. PDR bölümünde öğrenim gören öğrenciler, ileriki yıllarda ilk ve ortaöğretim okullarında rehber öğretmen olarak görev yapacakları için meslek öncesi eğitimlerde özellikle eğitsel rehberlik alanında "verimli ders çalışma, öğrenmeyi öğrenme" gibi konularda öğrenim görmekte, bilginin yeni bilimsel bulgular çerçevesinde değişebileceğine dair bir anlayış edinebilmektedirler. Bu nedenle onların "bilginin gelişimi" alt boyutundaki epistemolojik inançlarının diğer bölümlere göre daha yüksek olabilir. Bununla birlikte "bilginin gelişimi" dışındaki diğer alt boyutlarda öğretmen adaylarının öğrenim gördükleri bölümlere göre epistemolojik inançlarında anlamlı bir fark bulunmamıştır. Ayrıca öğretmen adaylarının ders çalışma yaklaşımlarında da öğrenim gördükleri bölümlere göre anlamlı bir fark bulunamamıştır. Olpak ve Korucu (2014) tarafından üniversite öğrencilerinin ders çalışma yaklaşımlarını inceleyen araştırmada da öğrencilerin ders çalışma yaklaşımlarının öğrenim gördükleri bölümlere göre değişmediği belirlenmiş olup, bu sonuç araştırmanın ortaya koyduğu bulgu ile uyumludur.

Araştırmanın bulgularından birisi de, ayda birden fazla kitap okuyan öğretmen adaylarının DÇYÖ “derin yaklaşım” alt boyutundaki puanlarının üç ayda bir kitap okuyan öğretmen adaylarına göre anlamlı derecede yüksek olduğu tespit edilmiştir. Okumak, anlamak içindir; yani anlamak okumanın 
sonucu değil, temelidir. Kişinin kendini geliştirmesi, üst düzey bilişsel becerilere sahip olması, kavrama ve yorumlama becerileri de okuma alışkanlığı ile ilgilidir. Bireyin bilişsel öğrenme sürecinde en önemli öğrenme alanlarından biri olan okuma ile elde edilen bilgiler çeşitli bilişsel işlemlerden geçerek zihinde yapılandırılmaktadır (Epçaçan, 2018). Derin öğrenme yaklaşımında yüzeysel ve ezbere ders çalışma yerine anlama, anlamlandırma ve yapılandırma söz konusu olduğu için ayda birden fazla kitap okuyan öğretmen adaylarının üç ayda bir kitap okuyan öğretmen adaylarına göre daha fazla derin öğrenme yaklaşımını tercih ettikleri düşünülebilir. Ders Çalışma Yaklaşımı Ölçeği diğer alt boyutlarında ve öğretmen adaylarının epistemolojik inançlarında kitap okuma sıklığına göre anlamlı fark bulunmamıştır.

Araştırmanın diğer bir bulgusu da öğretmen adaylarının epistemolojik inançları ile ders çalışma yaklaşımları arasında anlamlı bir korelasyonel ilişki bulunmamıştır. Epistemolojik İnanç "bilginin gerekçelendirilmesi" alt boyutu ile Ders Çalışma Yaklaşımı "derin yaklaşım” alt boyutu arasında düşük düzeyde pozitif yönde bir ilişki belirlenmiştir. Deryakulu (2004) tarafından yapılan çalışmada da epistemolojik inancın üniversite öğrencilerinin ders çalışma stratejilerini yordama gücünün zayıf olduğu sonucuna ulaşılmıştır ki bu sonuç bu araştırmanın bulgularıyla uyumludur.

Bütün bu sonuçlar çerçevesinde öğretmen adaylarının epistemolojik inançları ve ders çalışma yaklaşımlarını geliştirme konusunda eğitsel rehberlik faaliyetlerinin yürütülmesi, epistemolojik inanç ve ders çalışma yaklaşımlarını etkileyecek olumsuzlukları giderilmesi için akademik çalışmaların yapılması önerilmektedir. 
EXTENDED ABSTRACT

\title{
Examination of Epistemological Beliefs and Study Approaches of Teacher Candidates in Terms of Various Variables
}

\author{
İlhami Arseven- Mustafa Ersoy- Aylin Taşdemircanan \\ Cumhuriyet University - Cumhuriyet University-MONE
}

This study examined pre-service teachers' epistemological beliefs and study approaches according to various variables. Since the study included questions about beliefs and approaches based on personal opinions and expressions, the researchers decided to use the survey model as the research model. While the universe of the study consisted of teacher candidates studying at Sivas Cumhuriyet University Faculty of Education, the study group of a total of 178 teacher candidates studying in the last year of Psychological Counseling and Guidance (39), Science Teaching (27), Primary School Teaching (22), Preschool Teaching (51) and Turkish Language Teaching (39) departments. $74 \%$ of the teacher candidates in the study group were female and $26 \%$ of them were male. $22 \%$ of the participants were studying in the department of Psychological Counseling and Guidance, $15 \%$ of them were studying in the Science Teaching department, $12 \%$ of them were studying in the Primary School Teaching department, 29\% were studying in the Preschool Teaching department and 22\% were studying the in Turkish Language Teaching department. The researchers used the "Epistemological Belief Scale (EBS)", which was developed by Conley et al. (2004) and translated into Turkish and adaptated (for university students) by Akçay, Gezer, and Akçay (2016), who conducted validity and reliability study of the scale, and "Study Process Questionnaire (SPQ)", which was developed by Biggs, Kember, and Leung ( 2001) and the translated into Turkish and adapted by Yilmaz and Orhan (2011), who conducted validity and reliability study, to collect the data. The "Epistemological Belief Scale" aims to determine the epistemological beliefs of teacher candidates. The original scale consisted of 26 items and was a 5-point Likert scale. The study process questionnaire con- 
sisted of 20 items and was a 5-point Likert scale. In addition, the researchers used the "Personal Information Form" developed by themselves to reveal the demographic information of the teacher candidates, their personal qualities and the variables included in the study. The form included information about the gender of the teacher candidates participating in the study, the departments they studied and their frequencies of reading books. The researchers used SPSS 13.0 in the analysis of the data. The paper presented the descriptive statistics related to the first and third subproblems of the study in percentage and frequency values. In the analysis of the data related to the other sub-problems, the researchers first checked whether the data showed a normal distribution, and the analysis indicated that the data violated the normality assumption. The researchers conducted non-parametric Mann Whitney $U$ tests in order to determine whether there was a significant difference between the groups in bivariate cases from the data collected within the scope of the second and fourth sub-problems of the study and which did not show normal distribution, and in cases with more than two variables, the researchers conducted the Kruskall-Wallis tests (as the homogeneity test of the variances indicated that the variances were not homogeneous, the researchers conducted a post-hoc Games-Howell test). Spearman correlation test was conducted to analyze the data collected for the fifth sub-problem of the study. The results indicated no significant difference between the gender variable and the scores of the teacher candidates from the whole Epistemological Belief Scale and its sub-dimensions, and that the scores of the male teacher candidates in the sub-dimension of the "superficial approach" of the Study Process Questionnaire were significantly higher than the scores of the female teacher candidates. Furthermore, the results indicated that the scores of those studying in the Psychological Counseling and Guidance department in the "development of knowledge" sub-dimension of EBS were significantly higher than the scores of those studying in the departments of Primary School and Science Teaching. The study determined that there was no significant difference between the frequency of reading books variable and the scores of the teacher candidates in the whole Epistemological Belief Scale and its sub-dimensions, and that the scores of the pre-service teachers who read more than one book a month in the "deep approach" sub-dimension of the SPQ were significantly higher than those who read 
a book every three months. In addition, the results indicated a low level of positive correlation between the scores of the teacher candidates in the "justification of knowledge" sub-dimension of EBS and the scores they got from the "deep approach" sub-dimension of SPQ. The results indicated no significant correlation between teacher candidates' epistemological beliefs and their study approaches. The results determined a low-level positive correlation between the "justification of knowledge" sub-dimension of EBS and the "deep approach" sub-dimension of SPQ. The findings were interpreted and discussed based on the relevant literature. Within the framework of all these results, the researchers recommend to carry out educational guidance activities to help teacher candidates develop epistemological beliefs and study processes, and to carry out academic studies to eliminate the negativities that will affect epistemological beliefs and study processes.

\section{Kaynakça/References}

Akçay, B., Gezer, S.U. ve Akçay, H. (2016). Öğretmen adayları için epistemolojik inançlar ölçeği uyarlama çalışması. Erzincan Üniversitesi Eğitim Fakültesi Dergisi, 18(2), 1514-1536.

Alkın-Şahin, S., Tunca, N. ve Ulubey, Ö. (2014). Öğretmen adaylarının eğitim inançları ile eleştirel düşünme eğilimleri arasındaki ilişki. İlköğretim Online, 13(4), 1473-1492.

Altınkurt, Y., Yılmaz, K. ve Oğuz, A. (2012). İlköğretim ve ortaöğretim okulu öğretmenlerinin eğitim inançları. Ondokuz Mayıs Üniveristesi Eğitim Fakültesi Dergisi, 31(2), 1-19.

Aytaç, A. (2020). Öğretmen adaylarının epistemolojik inançlarının ve eğitim felsefesi eğilimlerinin öğretme ve öğrenme anlayışlar üzerindeki etkisi. (Doktora Tezi). Balıkesir Üniversitesi Sosyal Bilimler Enstitüsü, Balıkesir.

Bahar, H. H. ve Okur, M. (2018). Öğretmen adaylarının ders çalışma yaklaşımlarının akademik başarıyı yordama gücü. Cumhuriyet Uluslararası Ĕ̆itim Dergisi, 7(3), 307-318.

Beşoluk, Ş. ve Önder, İ. (2010). Öğretmen adaylarının öğrenme yaklaşımları, öğrenme stilleri ve eleştirel düşünme eğilimlerinin incelenmesi. İköğretim Online, 9(2), 679-693. 
Biçer, B., Er, H. ve Özel, A. (2013). Öğretmen adaylarını epistemolojik inançları ve benimsedikleri eğitim felsefeleri arasındaki ilişki. Journal of Theory and Practice in Education, 9(3), 229-242.

Biggs, J. (1999). What the student does: Teaching for enhanced learning. Higher Education, 18(1), 57-75.

Biggs, J. (2001). Enhancing learning: A matter of style or approach? R. J. Sternberg, L.-f. Zhang (Eds.), The educational psychology series. Perspectives on thinking, learning, and cognitive styles içinde (s.73-102). Lawrence Erlbaum Associates Publishers.

Biggs, J. and Tang, C. (2007). Teaching for quality learning at university (3rd ed.). Milton Keynes: Open University Press.

Biggs, J.B., Kember, D. and Leung, D.Y. (2001). The revised two-factor study srocess questionnaire: R-SPQ-2F. British Journal of Educational Psychology 71(1), 133- 149. DOI: 10.1348/000709901158433.

Büyükdüvenci, S. (1985). Epistemoloji ve eğitim. Ankara Üniversitesi Eğitim Bilimleri Fakültesi Dergisi, 18(1), 129-138.

Chan, K. W. (2003). Hong Kong teacher education students' epistemological beliefs and approaches to learning. Research in Education, 69, 36-50.

Chan, C. K. K. and Sachs, J. (2001). Beliefs about learning in children's understanding of science texts. Contemporary Educational Psychology, 26, 192-210.

Conley, A. M., Pintrich, P. R., Vekiri, I. and Harrison, D. (2004). Changes in epistemological beliefs in elementary science students. Contemporary Educational Psychology, 29, 186-204.

Çalık, D. ve Çınar, Ö.P. (2009). Geçmişten günümüze bilgi yaklaşımları bilgi toplumu ve internet. 2009 XIV. Türkiye'de İnternet Konferansı Bildirileri içinde (s.77-88). İstanbul: Bilgi Üniversitesi.

Çetin, B. (2016). Approaches to learning and age in predicting college students' academic achievement. Journal of College Teaching and Learning (Online), 13(1), 21-28. https://doi.org/10.19030/tlc.v13i1.956.

Çuhadar, C., Gündüz, Ş. ve Tanyeri, T. (2013). Bilgisayar ve öğretim teknolojileri öğrencilerinin ders çalışma yaklaşımlarının ve akademik öz-yeterlik algılarının incelenmesi. Mersin Üniversitesi Eğitim Fakültesi Dergisi, 9(1), 251-259.

Demir, M. K. (2000). İlköğretim bölümü öğretmen adaylarının epistemolojik inançlarının incelenmesi. Uludă̆ Üniversitesi Ĕ̆itim Fakültesi Dergisi, 25(2), 343-358. 
Demirel, Ö. (2003). Plandan değerlendirmeye öğretme sanatı. Ankara: Pegem Akademi.

Derbeder, F. (2007). Platon ve Aristoteles'te ruh beden problemi ve karşılaştırılması. (Yüksek Lisans Tezi) .Pamukkale Üniversitesi, Pamukkale Üniversitesi Sosyal Bilimler Enstitüsü, Denizli.

Deryakulu, D. (2004). Üniversite öğrencilerinin öğrenme ve ders çalışma stratejileri ile epistemolojik inançları arasındaki ilişki. Kuram ve Uygulamada Ĕ̆itim Yönetimi, 38, 230-249.

Dönmez, C., Yazıcı, K. and Demirez, G. M. (2016). Examination of social studies teacher candidates' study approaches. International Online Journal of Educational Sciences 8(2), 227-239.

Dweck, C. S. (1986). Motivational processes affecting learning. American Psychologist, 41(10), 1040-1048.

Dweck, C. S. and Leggett, E. L. (1988). A Social-cognitive approach to motivation and personality. Psychological Review, 95(2), 256-273.

Eick, C. J. (2000). Inquiry, nature of science and evolution: The need for a more complex pedagogical content knowledge in science teaching. Electronic Journal of Science Education, 4, 1-8.

Ellez, M. and Sezgin, G. (2002). Öğretmen adaylarının öğrenme yaklaşımları. V. Ulusal Fen Bilimleri ve Matematik Eğitimi Kongresi Bildiri Kitapçı̆̆ı Cilt II, s.1261-1266.

Epçaçan, C. (2018). Okuma ve okuduğunu anlama becerilerinin öğretim sürecine etkisi. Turkish Studies, 13(19), 615-630.

Ergün, M. (2015). Eğitim felsefesi. Ankara: Pegem Akademi.

Garner, R. and Alexander, P. A. (1994). Beliefs about text and instruction with Text. Hillsdale, NJ:Erlbaum.

Gill, M.G., Ashton, P. and Algina, J. (2004). Changing preservice teachers' epistemological beliefs about teaching and learning in mathematics: An intervention study. Contemporary Educational Psychology, 29, 164185.

Hofer, B. K. (2000). Dimensionality and disciplinary differences in personal epistemology. Contemporary Educational. Psychology, 25, 378-405.

Hofer, B.K. and Pintrich, P.R. (1997). The development of epistemological theories: beliefs about knowledge and knowing and their relation to learning. Review of Educational Research, 67(1), 88-140. 
Howard, B.C., McGee, S., Schwartz, N. and Purcell, S. (2000). The experience of constructivism: Transforming teacher epistemology. Journal of Research on Computing in Education, 32(4), 455-465.

İçen, M., İlğan, A. ve Göker, H. (2013). Sosyal bilgiler öğretmen adaylarının epistemolojik inançlarının analizi. Anadaolu Ĕ̆itim Liderlerliği ve Öğretim Dergisi, 1(2), 2-11.

İçen, M. ve Akpınar, E. (2016). Sosyal bilgiler öğretmenlerinin epistemolojik inançlarının sınıflarda uyguladıkları öğretim stratejilerine etkisi. Turkish Studies International Periodical for the Languages, Literature and History of Turkish or Turkic, 11(19), 443-460.

Jehng, J.J., S. Johnson M.D. and Anderson, R. J. (1993). Schooling and students epistemolocigal beliefs about learning. Contemporary Educational Psychology, 18, 23-35.

Johansen, D. H. (1991). Objectivism versus constructivism: Do we need a new philosophical paradigm? Educational Technology Research and Development, 39(3), 5-14.

Kaleci, F. (2012). Matematik öğretmen adaylarının epistemolojik inançlarn ile öğrenme ve öğretim stilleri arasındaki ilişki. (Yüksek Lisans Tezi). Necmettin Erbakan Üniversitesi, Eğitim Bilimleri Enstitüsü, Konya.

Karasar, N. (1999). Bilimsel Araştırma Yöntemi. Ankara: Nobel Yayın.

Keleş, H. (2013). Temel eğitim felsefesi akımları bağlamında john locke'un liberal eğitim anlayışı. (Yüksek Lisans Tezi). Erzurum Atatürk Üniversitesi, Sosyal Bilimler Enstitüsü, Felsefe Anabilim Dalı, Erzurum.

Kıralp, Y.A., Şahin, F.S. ve Dinçyürek, S. (2008). Denetim odağ farklı psikolojik danışmanlık ve rehberlik öğrencilerinin epistemolojik inançları. Buca Ĕ̆itim Fakültesi Dergisi, 23(23), 98-106.

Koç, S. ve Memduhoğlu, H.B. (2017). Öğretmen adaylarının epistemolojik inançları: Bir karma yöntem. Elektronik Sosyal Bilimler Dergisi, 16(60), 119-134.

Kuş, E. (2009). Nicel-Nitel araştırma teknikleri sosyal bilimlerde araştırma teknikleri nicel mi nitel mi? Ankara: Anı Yayıncıllk.

Lee, J.C., Zhang, Z., Song, H. and Huang, X. (2013). Effects of epistemological and pedagogical beliefs on the instructional practices of teachers: A Chinese perspective. Australian Journal of Teacher Education, 38(12), 120-146.

Marton, F and Säljö, R. (1976a). On qualitative differences in learning: I. Outcome and process. British Journal of Educational Psychology, 46, 4-11. 
Marton, F and Säljö, R. (1976b). On the qualitative differences in learning. II. Outcome and Process. British Journal of Educational Psychology, 46, 115-127.

Miller, C. D., Finley, J. and McKinley, D. L. (1990). Learning approaches and motives: Male and female differences and implications for learning Assistance Programs. Journal of College Student Development, 31(2), 147-154.

Müller, S., Rebmann, K. and Liebsch, E. (2008). Trainers' beliefs about knowledge and learning - A pilot study. European Journal of Vocational Training, 45- 2008/3 http://eric.ed.gov/PDFS/EJ836658.pdf Erişim Tarihi: Ocak, 2021.

Olpak, Y.Z. ve Korucu, A.T. (2014). Öğrencilerin ders çalışma yaklaşımlarının farklı değişkenler açısından incelenmesi. Ahi Evran Üniversitesi Kırşehir Ĕ̆itim Fakültesi Dergisi, 15(1), 333-347.

Oğuz, A. (2008). Investigation of Turkish trainee teachers epistemological beliefs. Social Behavior and Personality, 36(3), 709-720.

Ozan, C., Köse, E. ve Gündoğdu, K. (2012). Okul öncesi ve sınıf öğretmenliği öğrencilerinin öğrenme yaklaşımlarının incelenmesi. Ĕ̆gitim Bilimleri Araştırmaları Dergisi, 2(2), 75-92.

Perry, W. G. (1968). Forms of intellectual and ethical development in the college years: A scheme. Cambridge, MA: Bureau of Study Counsel, Harvard University.

Prosser, M. and Trigwell, K. (1999). Understanding learning and teaching: The exeperience in higher education. Buckingham: Society for Research into Higher Education/Open University Press.

Qian, G. and Alvermann, D. (1995). Role of epistemological beliefs and learned helplessness in secondary school students' learning science concepts from text. Journal of Educational Psychology, 87(2), 282-292.

Ravindran, B., Greene, B. A. and DeBacker, T. K. (2005). Predicting preservice teachers' cognitive engagement with goals and epistemological beliefs. The Journal of Educational Research, 98(4), 222-232.

Ryan, M.P. (1984). Monitoring text comprehension: Individual differences in epistemological standards. Journal of Educational Psychology, 76, 12261238.

Schoenfeld, A. H. (1983). Beyond the purely cognitive: Belief systems, social cognitions, andmetacognitions as driving forces in intellec-tual performance. Cognitive Science, 7,329-363. 
Schommer, M. (1990). Effects of beliefs about the nature of knowledge on comprehension. Journal of Educational Psychology, 82, 498-504.

Schommer, M. (1994). Synthesizing epistemological belief research: Tentative understandings and provocative confusions. Educational Psychology Review, 4, 293- 319.

Schommer-Aikins, M. (2004). Explaining the epistemological belief system: Introducing the embedded systemic model and coordinated research approach. Educational Psychologist 39(1),19-29.

Schommer, M., Crouse, A. and Rhodes, N. (1992). Epistemological beliefs and mathematical text comprehension: Believing it is simple does not make it so. Journal of Educational Psychology, 84(4), 435-443.

Schommer, M. and Dunnell, P. A. (1994). A Comparison of epistemological beliefs between gifted and non-gifted high school students. Roeper Review: A Journal on Gifted Education, 16(3), 207-210.

Schommer-Aikins, M., Mau, W., Brookhart, S. and Hutter, R. (2000). Understanding middle students' beliefs about knowledge and learning using a multidimensional paradigm. The Journal of Educational Research, 94(2), 120-127.

Sözer, M.A. ve Sel, B. (2015). John Dewey'in görüşlerinin ontolojik ve epistemolojik temelde irdelenmesi. Ahi Evran Üniversitesi Kırşehir Ĕ̆itim Fakültesi Dergisi, 16(3), 313-327.

Terzi, A.R., Şahan, H.H., Çelik, H. ve Zöğ, H. (2015). Öğretmen adaylarının epistemolojik inançları ile eleştirel pedagoji kriterleri arasındaki ilişki. Ĕ̆itim ve Öğretim Araştırmaları Dergisi, 4(1), 344-356.

Turan, E. Z. (2016). Eğitimin felsefi temelleri. A. Uzunöz (Ed.), Eğitim bilimine giriş içinde (s.125-148). Ankara: Pegem Akademi Yayınları.

Yıldız, H. (2010). Öğretmen adaylarının sahip oldukları öğrenme stilleri ve öğrenme yaklaşımları arasındaki ilişki. Birinci Ulusal Ĕ̆itim Programı ve Öğretimi Kongresi, Balıkesir.

Yılmaz, M.B. ve Orhan, F. (2011). Ders çalışma yaklaşımı ölçeğinin Türkçe formunun geçerlik ve güvenirlik çalışması. Eğitim ve Bilim, 36 (159), 69-83. 


\section{Kaynakça Bilgisi / Citation Information}

Arseven, İ., Ersoy, M. ve Taşdemircanan, A. (2021). Öğretmen adaylarının epistemolojik inançları ile ders çalışma yaklaşımlarının çeşitli değişkenler açısından incelenmesi. OPUS-Uluslararası Toplum Araştırmaları Dergisi, 18(Eğitim Bilimleri Özel Sayısı), 4686-4717. DOI:10.26466//opus.887464. 